\title{
Rubus Pharmacology: Antiquity to the Present
}

\author{
Kim E. Hummer \\ U.S. Department of Agriculture, Agricultural Research Service, National Clonal Germplasm Repository, \\ 33447 Peoria Road, Corvallis, OR 97333
}

\author{
Additional index words. ancient and traditional, medicine, blackberries, raspberries, Rubus
}

\begin{abstract}
The genus Rubus L., indigenous to six continents, includes blackberries, raspberries, and their hybrids and is commonly referred to as brambles or briers. Rubus species were a food and medicinal source for native peoples soon after the Ice Age. This short article presents only a sample of the wealth of historical reports of medicinal uses for Rubus. Brambles were documented in the writings of the ancient Greeks: Aeschylus, Hippocrates, Krataeus, Dioscorides, and Galen; Romans: Cato, Ovid, and Pliny the Elder; Asian medicinal traditions; traditional Chinese medicine; and the Ayurvedic tradition of India. Folk traditions of native peoples throughout the world have also applied Rubus for multiple medicinal uses. Although in modern times Rubus is grown for its delicious and vitamin-rich fruit for fresh and processed product consumption, the ancients used the whole plant and its parts. Stems, branches, roots, leaves, and flowers were used in decoctions, infusions, plasters, oil or wine extractions, and condensates. Decoctions of branches were applied to stop diarrhea, dye hair, prevent vaginal discharge, and as an antivenom for snakebites. Leaves were chewed to strengthen gums and plastered to constrain shingles, head scurf, prolapsed eyes, and hemorrhoids. Flowers triturated with oil reduced eye inflammations and cooled skin rashes; infusions with water or wine aided stomach ailments. Greeks and Romans recorded female applications, whereas the Chinese described uses in male disorders. The fruits of $R$. chingii are combined in a yang tonic called $f u$ pen $z i$, "overturned fruit bowl," and prescribed for infertility, impotence, low backache, poor eyesight, and bedwetting or frequent urination. The Leechbook of Bald described the use of brambles against dysentery, combining ancient medicinal knowledge with pagan superstition and herb lore. Medicinal properties of Rubus continue in Renaissance and modern herbals, sanctioning leaf infusions as a gargle for sore mouth, throat cankers, and as a wash for wounds; the bark, containing tannin, was a tonic for diarrhea; and root extract, a cathartic and emetic. Recent research has measured high ellagic acid, anthocyanin, total phenolics, and total antioxidant content in Rubus fruits. Fruit extracts have been used as colorants and are now being tested as anticarcinogenic, antiviral, antiallergenic, and cosmetic moisturizing compounds. From ancient traditions through conventional folk medicines to the scientific confirmation of health-promoting compounds, Rubus is associated with health-inducing properties.
\end{abstract}

Raspberry cultivation for fruit only became widespread in European countries by the 16th century (Jennings, 1988). Modern uses of Rubus, the blackberries and raspberries, include consumption as delicious fresh fruits and processed in jams, jellies, pastries, dairy products, and juices (Daubeny, 1996). Many breeders throughout the United States and Canada have developed plants with large succulent fruits having delicate sugar-acid ratios and complex flavors. These small or soft fruits have high antioxidant capacity, high anthocyanins, high vitamins, simple sugars, and high mineral content (Määtä-Riihinen et al., 2004; Moyer et al., 2002). Ancient references of Rubus in Western and Eastern traditions do not refer to berries as food; rather the stems, leaves, and other plant parts were prized for their medicinal properties (Beck, 2005). The object of this review is to summarize the uses of Rubus for health from antiquity to the present from a sampling of the wealth of historical data on this subject. Although the recent use of the fruits as fresh and processed foods represents a global mul-

Received for publication 14 July 2010. Accepted for publication 3 Sept. 2010.

Financial support from USDA ARS CRIS 535821000-038-00D is acknowledged. The critical reviews by Dr. Jules Janick, Dr. Nahla Bassil, and Dr. Doug Holland are appreciated.

This paper was part of the workshop "Horticulture and Health: Historical Resources" held 26 July 2009 at the ASHS Conference, St. Louis, MO, and sponsored by the History of Horticultural Science (HIST) Working Group.

e-mail Kim.Hummer@ars.usda.gov. timillion dollar industry annually, interest in the medicinal qualities continues to expand.

\section{The genus Rubus}

Distribution. The genus Rubus, one of the most diverse in the plant kingdom, contains $\approx 740$ species that have been divided into 12 or 15 subgenera, depending on the botanist (Daubeny, 1996; Jennings, 1988). These diverse species are native on six continents and have been found from the tops of mountains to coastal locations at sea level (Thompson, 1995). Although the raspberries and blackberries are common in cool temperate regions of the northern hemisphere, the majority of Rubus species are native to South Pacific Islands.

Taxonomy. Blackberries are botanically classified in the genus Rubus subgenus Rubus (formerly Eubatus). European blackberries (Rubus fruticosus L. agg.) have a center of origin in the Caucasus, are well distributed throughout Europe, and have been introduced into Asia, Oceania, and North and South America. Subgenus Idaeobatus includes the European raspberries (Rubus idaeus L.) and the cloudberry ( $R$. chamaemorus L.) native to southern European mountains (Tutin et al., 1980 ) and were named by Linnaeus for Mount Ida, Turkey; North American raspberries $(R$. strigosus Michx., $R$. spectabilis Pursh, $R$. parviflorus Nutt.) and black raspberries (eastern, $R$. occidentalis L. and western, $R$. leucodermis Douglas ex Torr. \& A. Gray); and Asian species such as $R$. chingii $\mathrm{Hu}, R$. coreanus Miq., R. crataegifolius Bunge, and R. parvifolius L. This species is mainly distributed in Zhejiang, Fujian, Hubei, and Guizhou provinces of China. Rubus hawaiiensis A. Gray from Hawaii as well as species in East and South Africa are among many used by native peoples.

\section{Rubus medicinal uses}

Plants synthesize a variety of medically active phytochemicals, but most are derivatives of alkaloids, phenolics, terpenoids, and glycosides. The phenolics are the biochemical motif most active in Rubus plants for ethnomedicinal applications. Rubus phenolics include the flavonoids, potent in vitro antioxidants, including compounds such as flavones, isoflavones, flavonones, catechins, and the red, blue, and purple pigments known as anthocyanins (Määtä-Riihinen et al., 2004; Moyer et al., 2002). Tannins, present in Rubus stems and leaves, have astringent properties. Many cultures, without knowledge of the particular chemical agents, have observed medicinal properties in Rubus and applied them in different ways (Gunther, 1934; Rohde, 1922).

Prehistory. The use of herbs in the western hemisphere stretches back into antiquity, well into the Paleolithic or Old Stone Age era, $\approx 40,000$ BCE. Rubus species were a food source and medicinal plant for native peoples soon after the Ice Age (Connolly, 1999). In the New World, archeologists found evidence of Rubus as a food source in Newberry Crater near Bend, OR. Radiocarbon dating puts the artifacts and food remnants at $\approx 8000$ BCE (Connolly, 1999).

Antiquity. Brambles were documented in the writings of Aeschylus (Hendrickson, 1981) and Hippocrates, between 500 to $\approx 370$ BCE. Hippocrates recommended blackberry (batos) stems and leaves soaked in white wine as an astringent poultice on wounds and in difficulties 
of childbirth (Littre, 1979). Raspberries were harvested by the ancient Greeks as early as 370 BCE (Handley and Pritts, 1989). Pompey introduced raspberries from southeast of Troy in what is now Turkey to Rome $\approx 65$ BCE (Trager, 1995). Ancient Egyptians knew of the blackberry but did not document uses for it. Egyptian words for blackberry were "aimoios" or "ametros" approximately the second century CE (Manniche, 1989).

The earliest published blackberry descriptions and image (Fig. 1) can be found on fol. $82 \mathrm{v}-83 \mathrm{r}$ of the Juliana Anicia Codex or Vindobonensis Codex (Hummer and Janick, 2007). This image is very similar to fol. 32 of another Dioscoridean manuscript called Codex Neapolitanus, which, despite its crudeness, is more botanically precise, suggesting the possibility of a lost common archetypic illustration (Hummer and Janick, 2007). The Juliana Anicia Codex is a magnificently illustrated manuscript with written information based on the Peri Ylis Iatrikis (De Materia Medica in Latin; Of Medical Matters of Dioscorides). This book, one of the earliest that now survives, was originally presented to the imperial Princess Juliana Anicia in Constantinople $\approx 512 \mathrm{CE}$ (Collins, 2000). In the 15 th century it was purchased by the Emperor Maximilian for the Imperial Library and it was moved to Vienna, where it now resides. The translation of the Byzantine Greek written around the margins of the blackberry image on fol. $83 \mathrm{r}$ inspired the search for medicinal uses of Rubus, presented in this manuscript.

The Dioscorides text was first translated into English by John Goodyer in 1655 (Gunther, 1934), but a recent translation by Beck (2005), based on a more authoritative German translation by Wellman (1906-1914), is provided (Table 1). The first uses of Rubus (batos) state that a decoction of the branches contracts, binds, and dyes hair. Interestingly, although the ancient Greeks and Romans had numerous physical maladies to contend with, a top desire in health was to keep up an appearance of looking younger; dying hair would be a priority. Other uses included preventing stomachaches, stopping excess fluxes of bodily fluids particularly in the female plus far-ranging assistance for a multitude of symptoms, including droopy eyes, mouth sores, hemorrhoids, and snakebites. These uses described in the Juliana Anicia Codex were reiterated in many recensions of Dioscorides works for the next several millennia (Collins, 2000; Hummer and Janick, 2007).

Medieval. The image of the Leyden Apuleius is dissimilar and much inferior (Fig. 2) to that of the Juliana Anicia Codex (Fig. 1). In Medieval times, the basic information for the medicinal uses was similar to that of the ancient Greek and Latin texts, but the writings were imbued with pagan superstition and Christian ritual during the medieval period.

The Leechbook of Bald is an Anglo-Saxon herbal from Winchester prepared in $920 \mathrm{CE}$. "Loece" in Old English means healer; a leechbook was a physician's desk reference (Rohde, 1922). Leechbooks were consulted to determine what kind of blood letting was

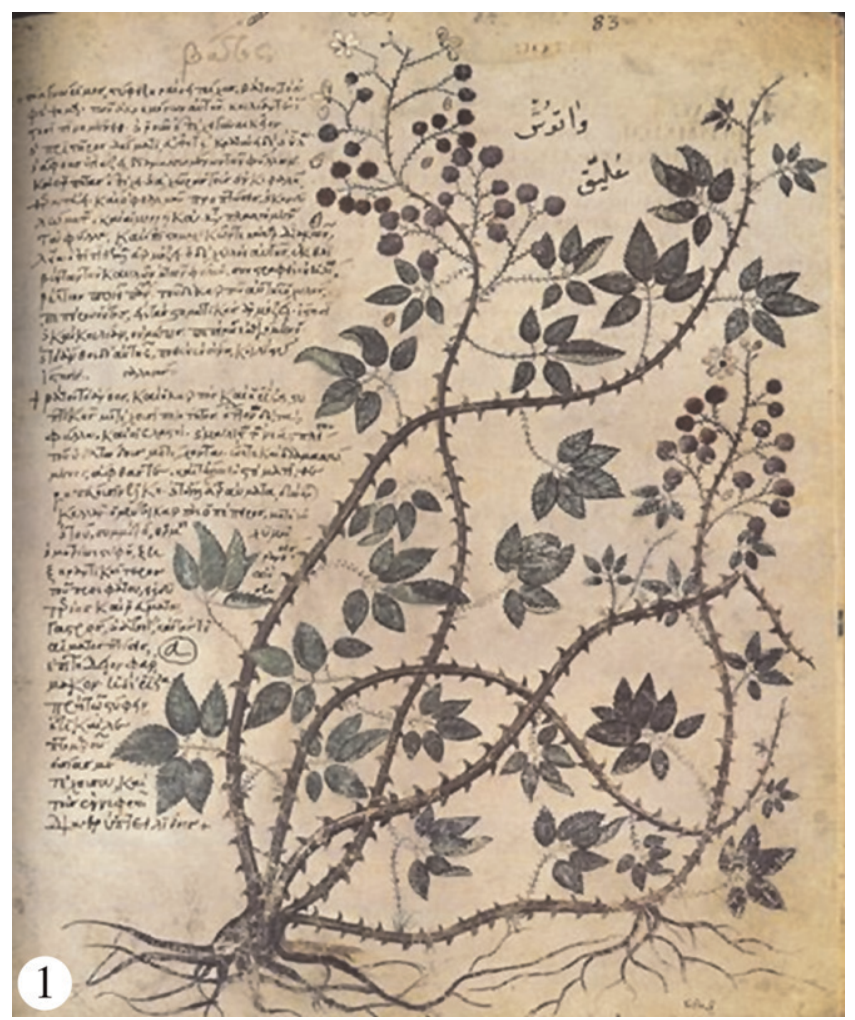

Fig. 1. Blackberry, Batos image Juliana Anicia Codex Vienna, Österreichische Nationalbibliothek, Cod. Med.gr.1. fol. 83r. 512 CE. Vienna. The text on the side gives medicinal uses for blackberry and raspberry plant tissues in Byzantine Greek.

Table 1. English translation of reference to Rubus spp. in De Materia Medica of Dioscorides (Beck, 2005). Book, section

IV, 37

Translation

[Bó $\tau_{0 \zeta}$ (batos), Rubus ulmifolius Schott, Bramble]

The bramble is a familiar plant. The decoction of its branches contracts, desiccates, dyes hair, and stops diarrhea when drunk, keeps in control, leucorrhea, and is suitable for the bite of the prester [A kind of serpent whose bite is poisonous]

When chewed, the leaves strengthen the gums and heal the thrush; plastered on, they keep in control shingles, treat head scurf, prolapses of the eyes, callous lumps, and hemorrhoids, and they are suitable to apply ground up on those with stomach and heart ailments. But its juice, extracted from the stems and leaves and condensed in the sun, will accomplish everything better. The juice of its fully ripened fruit is suitable for mouth ailments, its half-ripe fruit stops diarrhea when eaten, and its flower checks diarrhea when drunk with wine.

IV, 38 [Bó

The raspberry (Idaian bramble): it was named so because a great deal of it grows on mount Ida [in Turkey]. It is much softer than the previous one, having small thorns. But it is also found without thorns.

It can treat the same conditions as the one before it, but its flower helps far more for eye inflammations when triturated with oil and smeared over them; it also cools erysipelas and it is given in a drink with water to those with stomach problems.

necessary, if any, whether the patient should rest more or exercise more, if a change of diet were in order, or what medication or herbal remedies were needed. This book was scribed by a monk named Cild under the direction of another monk named Cyril Bald, who most probably was a personal friend of King Alfred (Rohde, 1922). The Lachbook of Bald contained 109 leaves and was written in a large bold hand with one or two of the initial letters faintly illuminated. A Saxon image of blackberry at the time of the Læch book of Bald, $\approx 920 \mathrm{CE}$, is diagrammatic (Fig. 3).

The Lachbook of Bald was written in the vernacular by men who were not Latin scholars. The medical knowledge originally based on pagan superstition combined with herb lore was absorbed into Christian tradition: "Against dysentery, a bramble of which both ends are in the earth [tip layer!] take the newer root, delve it up, cut up nine chips with the left hand and sing three times the Miserere mei Deus and nine times the Mater Noster, then take mugwort and everlasting, boil these three worts and the chips in milk till they get red, then let the man sip at night fasting a pound dish full...let him rest himself soft and wrap himself up warm; if more need be let him do so again, if thou still need do it a third time thou wilt not need oftener," Leechbook II 65 (Rohde, 1922).

The image of the blackberry in Bodley 130 Apuleius Platonicus suggests blackberries 


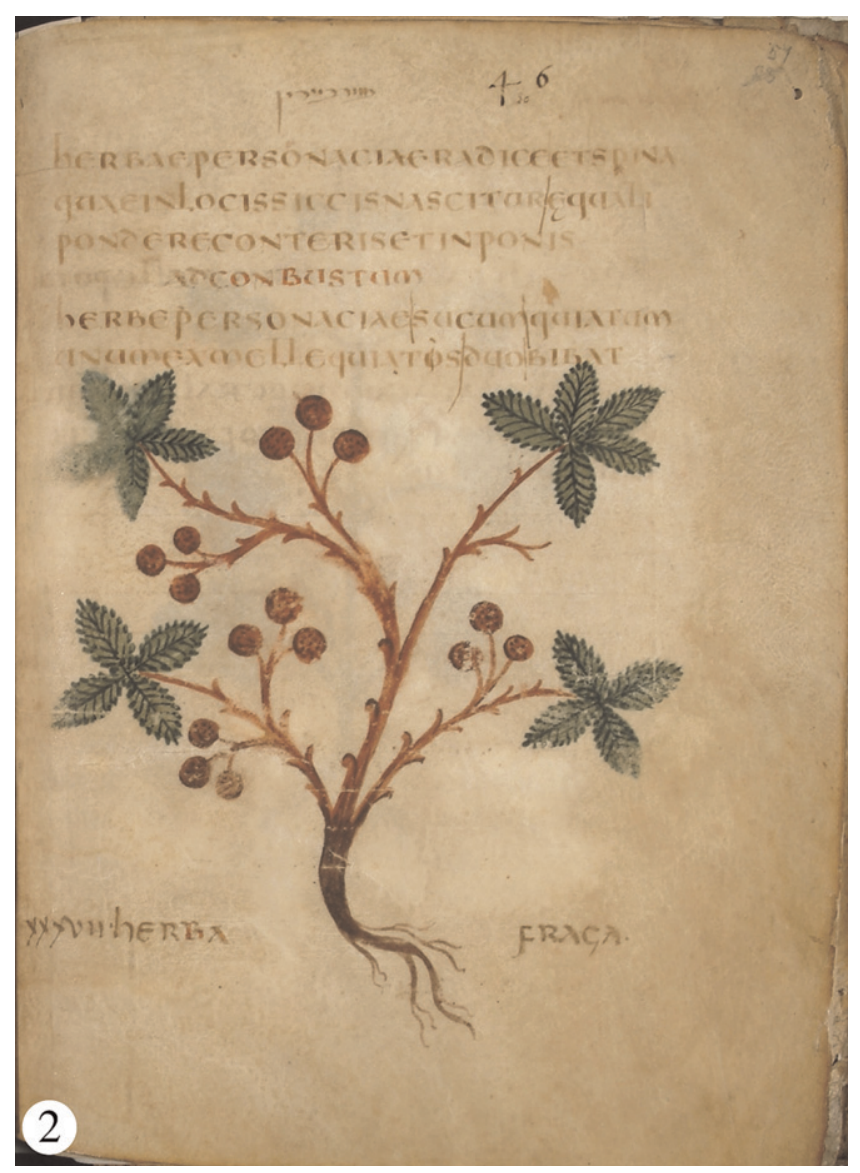

Fig. 2. Image of blackberry from the Leyden Apuleius 600 CE (Singer, 1958; Fig. 80).

without botanical precision (Fig. 4). The medicinal use is similar to that written in Dioscorides recensions.

Although raspberry (framboise in French) and blackberry (ronce in French) are illustrated in Manuscript Latin 9474 (Les Grandes Heures d'Anne de Bretagne, 1503 to 1508), respectively, on folio 20 (http://visualiseur. bnf.fr/Visualiseur?Destination=Mandragore $\&$ $\mathrm{O}=7833778 \& \mathrm{E}=1 \& \mathrm{I}=68538 \& \mathrm{M}=$ imageseule) and folio 206 (http://visualiseur.bnf.fr/Visua liseur?Destination=Mandragore $\& \mathrm{O}=7834164$ $\& \mathrm{E}=1 \& \mathrm{I}=68849 \& \mathrm{M}=$ imageseule), no medicinal use is mentioned in this prayer book.

Renaissance. Although records indicate that Henry III's clerk bought raspberries for the king's drinks (Jennings, 1988), nothing much was written of them until almost the 16th century when Matthioli wrote about raspberries being collected from the woods and brought into the gardens in Bohemia. According to Jennings (1988), yellow forms were recorded by Canerarius in 1588 and by Clusius in 1601. Heresbach (1570) indicated that raspberries were not very popular.

Turner (1548) mentioned the "soure" taste of red raspberries (English raspes or hyndberries) and that they "grow most plenteously in the wooddes in east Friesland" and "grow in certayne gardines in Englande."

Gerard's Herbal, a famous English herbal published in 1597, contains realistic images of red raspberries using wood cuts and sum- marizes medicinal and horticultural information (Woodward, 1927). Gerard starts out with a description of the plant and then goes into the uses and qualities. His uses include healing the eyes that hang out; leaves of bramble boiled in water with honey, alum, and a little white wine make an excellent lotion and washing water; and the same decoction fastens the teeth. John Parkinson (1629) wrote of red, white, and thornless "raspis-berries" that grow in the English climate.

By Culpeper's (1652) time brambles were so well known that this plant "needeth no description." By his determination, astrological connections were an important facet of herbal use. The virtues of these tasty fruits indicate that "Venus in the house of Aries," although the prickers (an un-Venus-like trait) occur because, for this plant, "Venus is in the house of Mars." Besides adding the astrological references, Culpeper regurgitated the teachings of the ancient Greek and Roman traditions. Brambles continued to be used for dying hair, binding the belly, and soothing the mouth. Other uses included a decoction of the leaves as a gargle for throat cankers and as a wash for wounds. The bark, containing tannin, was a tonic for diarrhea. Extracts of the roots were a cathartic and emetic.

Traditional Indian medicine (Ayurveda). The Indian medical tradition of the Ayurveda is based on Sanskrit texts from $\approx 200 \mathrm{CE}$, which link health to spirituality. Health is the result of external influences such as lifestyle and diet combined with internal influences (Trawick, 1995). Disease is disequilibrium, and the use of herbs contributes to the restoration of balance. Ancient Greek medicine has striking similarities to Ayurvedic medicine because both systems are based on "humors."

The Indian medicinal uses of Rubus include application of the astringent diuretic action of the leaves and bark. Raspberry leaves are combined with many other herbs to produce kasaya. The action of a decoction of this herb mixture produces clarity, causes stiffening of the mouth, contracts the tongue, provides a feeling of heaviness, and diminishes saliva. The infusion of Rubus leaves is alleged to aid in stomach problems, childbirth, and menopause.

The native Rubus species of Europe such as the blackberry, Rubus fruticosus, and the red raspberry, Rubus idaeus, are not endemic in India but were brought there through human exchange from east to west along the Silk Roads. Many web-related nutraceutical applications of Ayurvedic medicine promote the use of accessible European Rubus species such as the red raspberries rather than Asian ones, e.g., Rubus coreanus, $R$. crataegifolius, or $R$. parvifolius.

Traditional Chinese medicine. The Shen Nung Ben Tsao (25 to $220 \mathrm{CE}$ ), the Herbal Classic, is considered to be the oldest book on oriental herbal medicine (Hsu et al., 1986). It classifies 365 species of roots, grasses, woods, furs, animals, and stones into three categories of herbal medicine. Among the herbal remedies described is Fu pen zi, (覆盆子), Fructus Rubi, which is commonly composed of fruits of $\mathrm{R}$. chingii, one of the Chinese raspberry species. Fu pen zi means "upside-down bowl." This may refer to the shape of an overturned raspberry fruit, or an overturned chamber pot, because of the plant's enuretic effects. In traditional Chinese medicine, Chinese raspberries are considered to have sweet and warm properties and are associated with the liver and kidney meridians. They function to tonify and stabilize the kidneys to preserve vital energy and treat cases of liver and kidney deficiency. The uses of Chinese raspberry are alleged to include: preventing frequent urination, enuresis, premature ejaculation, impotence; reducing sore lower back; improving eyesight or blurry vision; and preventing uterine, cervical, and colon cancer.

Folk medicine. Ethnomedicinal uses of Rubus can be found in many cultures. Indigenous folk medicine from native peoples of Oceania, Africa, and America include Rubus, which is naturally distributed on six of the seven continents. These include strengthening pregnant women, relieving morning sickness, aiding in childbirth, stimulating the uterus at the beginning of labor, and relieving menstrual cramps.

In Australia, aboriginal people used a decoction of raspberry leaves as a traditional treatment for diarrhea (Symons and Symons, 1994). Leaves were made into tea, which was considered helpful for painful menstruation, childbirth, flu, and morning sickness. The fruit 
is considered a mild laxative if eaten in large quantities.

In Hawaii, the Hawaiian term for their native raspberry species ( $R$. hawaiiensis) is "akala." The ash of dried akala stem and naupaka (Scaevola spp.) was used for kepia (dandruff) (Chock, 1968). Ashes of akala stem and ripe he'i (papaya, Carica papaya) are ingested as a treatment for umauma naha (burning effect in the chest) and hoaoa lua' $i$ (stomach ailment with vomiting).

In the Pacific Northwest, native peoples used $R$. leucodermis, $R$. parviflorus, and $R$. spectabilis (Gunther, 1973) for medicinal uses. The Quileutes from western Washington State chewed the leaves or bark and spit them to clean infected wounds, especially burns. They also boiled the bark in seawater, and the brew was drunk to lessen labor pains. The Makah pounded the bark and laid it on aching teeth or festering wounds.

Recent research. Current investigations have identified Rubus fruit as a source of bioactive phenolic antioxidants. These compounds have a strong capacity to scavenge oxygen radicals. They inhibit oxidation and the growth of pathogenic bacteria and inhibit growth of certain cancer cell lines in vitro.

Moyer et al. (2002) analyzed dark-pigmented fruit from Rubus, Vaccinium, and Ribes. The black raspberry ( $R$. occidentalis) cultivars had the highest total anthocyanins observed of genotypes of Ribes, Rubus, and Vaccinium (Table 2). Black raspberry extract was used in the early 20th century as a dye stamp for meat inspection in the United States and as a food colorant (Moyer et al., 2002). Määtä-Riihinen et al. (2004) analyzed fruits of three Rubus species and observed Quercetin 3-glucuronide typical flavonol glycoside. The cyanidin glycosylation forms could separate species of Rubus through chemotaxonomic analysis. Ellagic acid was present as free and glycosylated forms and ellagitannins; other reportedly anticarcinogenic compounds were also present.

Evidence suggests that Rubus and other berry fruits may have beneficial effects against several types of human cancers (Seeram, 2008). Studies show that the anticancer effects of berry bioactives are partially mediated through their abilities to counteract, reduce, and also repair damage resulting from oxidative stress and inflammation. In addition, berry bioactive chemicals also regulate carcinogen and xenobiotic metabolizing enzymes, various transcription and growth factors, inflammatory cytokines, and subcellular signaling pathways of cancer cell proliferation, apoptosis, and tumor angiogenesis. Berry phytochemicals may also potentially sensitize tumor cells to chemotherapeutic agents by inhibiting pathways that lead to treatment resistance, and berry fruit consumption may provide protection from therapy-associated toxicities (Seeram, 2008).

\section{CONCLUSION}

Just as diverse Rubus species are found throughout the world, diverse uses for Rubus

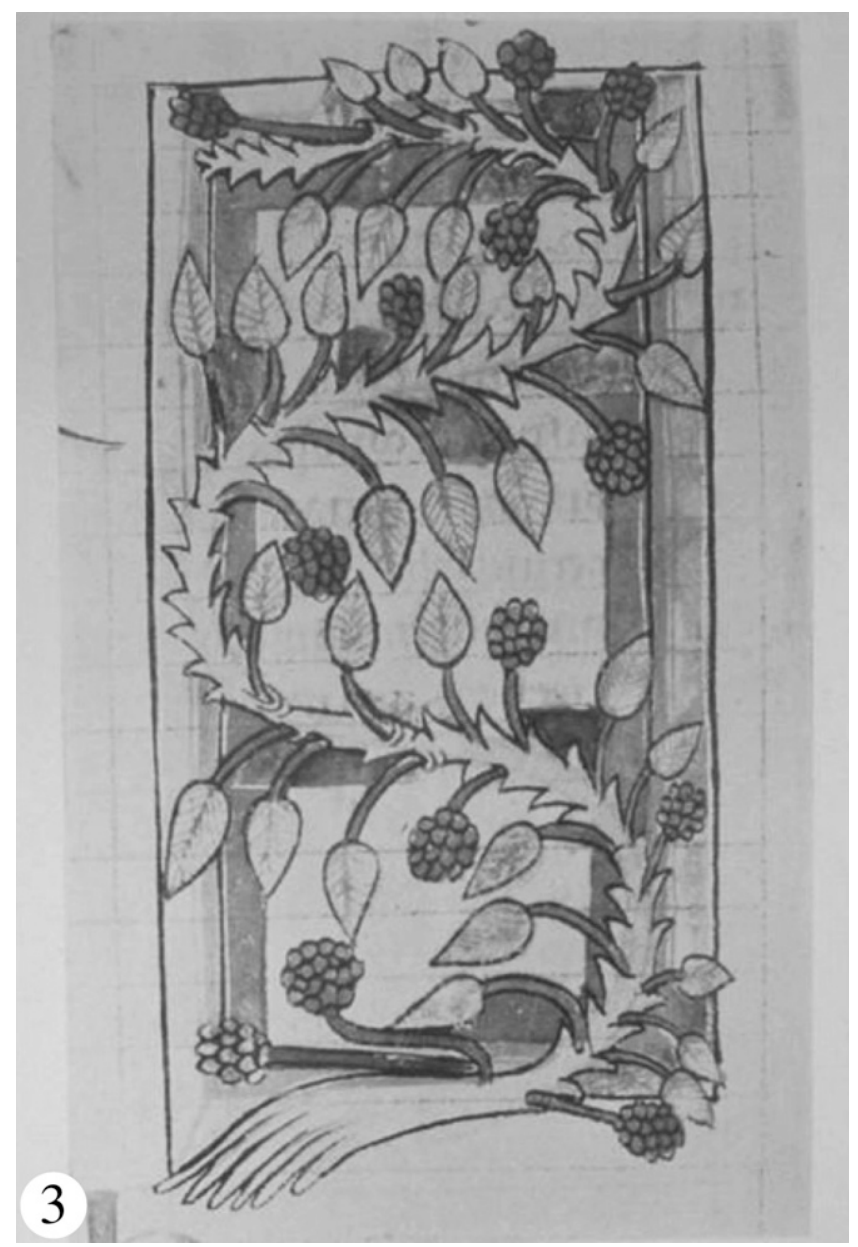

Fig. 3. Saxon image of blackberry at the time of the Læchbook of Bald, about 920 CE. Sloane 1975 , folio 37a, in Rhone, 1922.

Table 2. Total anthocyanin (ACY), berry count, and total phenolics (TPH) of blueberries, black currants, blackberries and black raspberries (Moyer et al., 2002).

\begin{tabular}{|c|c|c|c|}
\hline \multirow[b]{2}{*}{ Genotype } & $\mathrm{ACY}$ & Berries & TPH \\
\hline & \multicolumn{3}{|c|}{$\mathrm{mg} / 100 \mathrm{~g}$ per $100 \mathrm{~g} \mathrm{mg} / 100 \mathrm{~g}$} \\
\hline \multicolumn{4}{|c|}{ Vaccinium corymbosum L., blueberries } \\
\hline Bluecrop & $84 \pm 1.0$ & 91 & $304 \pm 15$ \\
\hline Brigitta Blue & $103 \pm 1.7$ & 56 & $246 \pm 5.4$ \\
\hline Duke & $173 \pm 8.1$ & 64 & $274 \pm 18$ \\
\hline \multicolumn{4}{|l|}{ Ribes nigrum L., black currant } \\
\hline Ben Conan & $162 \pm 4.2$ & 66 & $498 \pm 15$ \\
\hline Ben Lomond & $261 \pm 5.2$ & 91 & $933 \pm 36$ \\
\hline Ben Nevis & $252 \pm 6.2$ & 60 & $815 \pm 25$ \\
\hline Blackdown & $216 \pm 1.0$ & 128 & $812 \pm 33$ \\
\hline Boskoop & $240 \pm 2.7$ & 125 & $796 \pm 3.6$ \\
\hline Consort & $411 \pm 12$ & 176 & $1342 \pm 28$ \\
\hline \multicolumn{4}{|c|}{ Rubus section Rubus, blackberries } \\
\hline Cherokee (erect) & $123 \pm 4.5$ & 13 & $407 \pm 20$ \\
\hline Chester (semierect) & $164 \pm 1.1$ & 15 & $361 \pm 8.1$ \\
\hline Marion (trailing) & $230 \pm 2.1$ & 21 & $560 \pm 5.3$ \\
\hline Navaho (erect) & $126 \pm 2.5$ & 17 & $304 \pm 6.2$ \\
\hline Siskiyou (trailing) & $133 \pm 3.7$ & 11 & $543 \pm 10$ \\
\hline Triple Crown (semierect) & $113 \pm 3.9$ & 10 & $275 \pm 0.3$ \\
\hline \multicolumn{4}{|c|}{ Rubus occidentalis L., black raspberries } \\
\hline Earlysweet & $464 \pm 7.8$ & 74 & $897 \pm 32$ \\
\hline Jewel & $607 \pm 2.5$ & 52 & $1079 \pm 34$ \\
\hline Munger & $627 \pm 8.3$ & 71 & $890 \pm 30$ \\
\hline
\end{tabular}

appear in each of the traditions of ancient medicine as well as in the folklore from the cultures of indigenous people on each continent. Rubus plants have played a low but consistent role in the pharmacology of herbal medicines throughout the history of the world.

Although traditional medicinal uses of Rubus consider the applications of astringent 


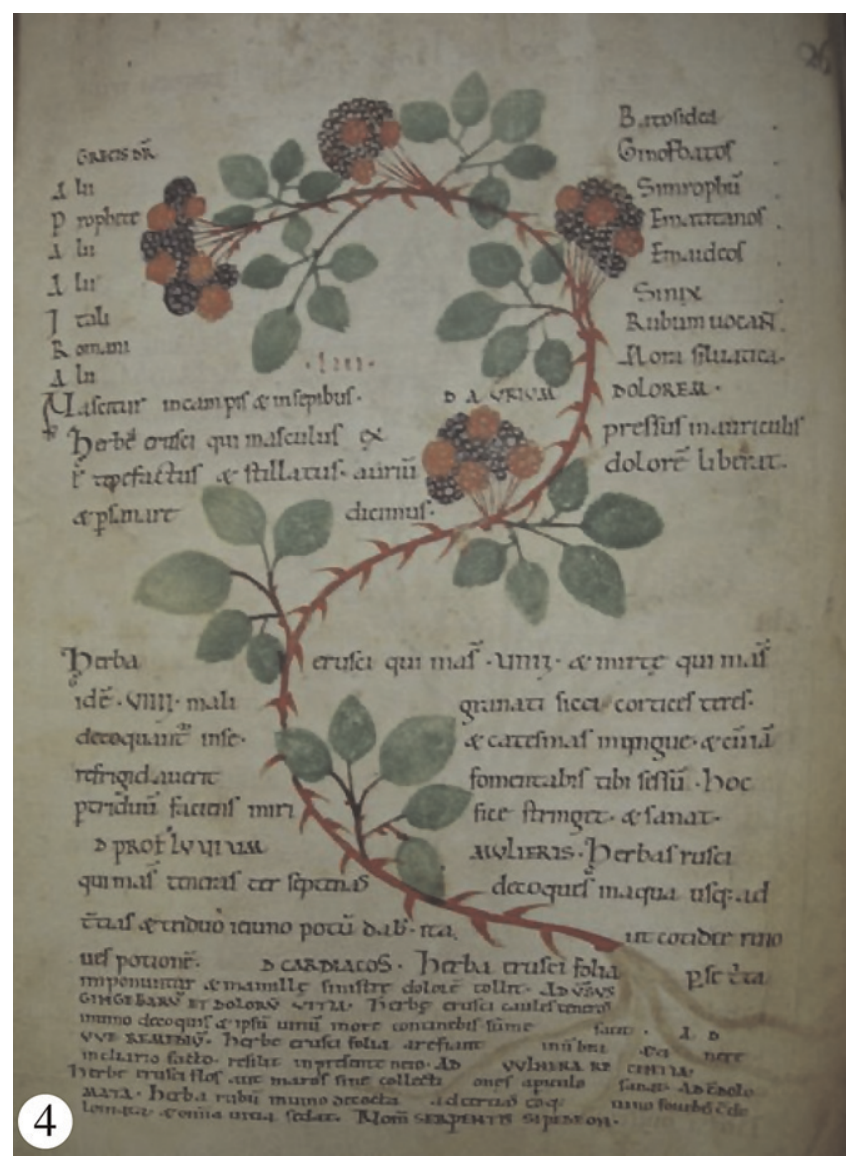

Fig. 4. Bramble, Rubus fruticosus with Latin text from Bodley 130 Apuleius Platonicus Codex, fol. 26r. Abbey of Bury St. Edmonds. ca. 1120 CE. Bodleian Library, Oxford, UK.

action of plants, stems, and leaves, modern focus resides in the phytochemical action of the ingested berries at the cellular and molecular levels. Research on the effects of berry nutrients on human health, the interaction between diet and disease, and metabolomics of berry phenolics are active areas of discovery. Rubus berry phytochemicals may act as "prodrugs" within target tissue sites or to promote colonic microflora to contribute to health benefits (Seeram, 2008). The consumption of Rubus fruits demonstrates a contribution in the prevention of chronic human diseases, improvement of quality of life, and promotion of healthy aging. The pharmacology of Rubus presents not only a textbook study of ancient wisdom, but suggests a potential health benefit in humanity's future.

\section{Literature Cited}

Beck, L.U. 2005. Pedanius Dioscorides of Anazarbus: De Materia Medica. Olms-Weidmann, Hildensheim, Germany. Preface, Introduction, and p. 264.

Blunt, W. and S. Raphael. 1979. The illustrated herbal. Frances Lincoln Pub. Ltd., London, UK.

Chock, A.K. 1968. Hawaiian ethnobotanical studies 1: Native food and beverage plants. Econ. Bot. 22:221-238.

Collins, M. 2000. Medieval herbals: The illustrative traditions. The British Library, London, UK. p. 39-105.

Connolly, T.J. 1999. Newberry Crater: A tenthousand-year record of human occupation and environmental change in the basin-plateau borderlands. Anthropological Papers No. 121, University of Utah, Salt Lake City, UT.

Culpeper, N. 1652. The English physitian: Or an astrologo-physical discourse of the bulgar herbs of this nation. Peter Cole Printing Press, Cornhill, UK.

Daubeny, H.A. 1996. Brambles, p. 109-190. In: Janick, J. and J.N. Moore (eds.). Fruit breeding: Vol. II. Vine and small fruit crops. Wiley, New York, NY

Der Wiener Dioskurides. 1998. Codex medicus graecus 1 der Osterreichischen Nationalbibliothek (Glanzlichter der Buchkunst) [in German].

Gunther, E. 1973. Ethnobotany of western Washington. The knowledge and use of native plants by Native Americans.. University of Washington Press, Seattle, WA. p. 34-36.

Gunther, R.T. (ed.). 1934. The Greek herbal of Dioscorides (1655/1933) translated by John Goodyer. Oxford, UK. Preface and p. 431-432.

Handley, D. and M. Pritts (eds.). 1989. Bramble production guide. Northeast Regional Agr. Eng. Serv. NRAES-35, Ithaca, NY.

Hendrickson, 1981. The berry book. Doubleday, New York, NY.

Heresbach, Conrad 1570. Foure books of husbandry [in English]. Rei rusticate libri quatuor [in Latin].

Hsu, H.-Y., C. Yuh-pan, S.-J. Shen, H. Shau-shin, C.-C. Chen, and C. Hsien-chang. 1986. Oriental Material Medica: A concise guide. Oriental Healing Arts Inst., Taiwan. p. 544-545.

Hummer, K. and J. Janick. 2007. Rubus iconography: Antiquity to the Renaissance. Acta Hort. 759:89-106.

Jennings, D.L. 1988. Raspberries and blackberries: Their breeding, diseases and growth. Academic Press, London, UK.
Littre, E. 1979. Oeuvres complètes d'Hippocrate. Traduction Nouvelle avec le texte Grec en regard. Adolf M. Hakkert, Amsterdam, The Netherlands. 7:217, 417

Littre, E. 1979. Oeuvres complètes d'Hippocrate. Traduction Nouvelle avec le texte Grec en regard. Adolf M. Hakkert, Amsterdam, The Netherlands. 10:777.

Määtä-Riihinen, K.R., A. Kamal-Eldin, and A. Riitta Törrönen. 2004. Identification and quantification of phenolic compounds in berries of Fragaria and Rubus species (Family Rosaceae). J. Agr. Food Chem. 52:6178-6187.

Manniche, L. 1989. An ancient Egyptian herbal University of Texas Press, Austin, TX. p. 163-167.

Moyer, R., K. Hummer, C. Finn, R. Wrolstad, and B. Frei. 2002. Anthocyanins, phenolics, and antioxidant capacity in diverse small fruits: Vaccinium, Rubus, and Ribes. J. Agr. Food Chem. 50:519-525.

Parkinson, J. 1629. Paradisi in Sole Paradisus Terrestris. Printed by Humfrey Lownes and Robert Young at the Signe of the Starre on Bread-Street Hill, London.

Rohde, E.S. 1922. The old English herbals. Longmans Green and Co., London, UK. p. 30-36.

Seeram, N.P. 2008. Berry fruits for cancer prevention: Current status and future prospects. J. Agr. Food Chem. 56:630-635.

Singer, C. 1958. From magic to science: Essays on the scientific twilight. Dover, New York. pp. 1-52.

Symons, P. and S. Symons. 1994. Bush heritage: An introduction to the history of plant and animal use by aboriginal people and colonists in the Brisbane and Sunshine Coast areas. Queensland, Australia. Pat and Sim Symons, Nambour, Qld. 106 pp.

Thompson, M.M. 1995. Chromosome numbers of Rubus species at the National Clonal Germplasm Repository. HortScience 30:1447-1452.

Trager, J. 1995. The food chronology: A food lover's compendium of events and anecdotes from prehistory to the present. Henry Holt and Co., New York, NY.

Trawick, M. 1995. Writing the body and ruling the land: Western reflections on Chinese and Indian medicine, p. 276-296. In: Bates, D. (ed.). Knowledge and the scholarly medical traditions. Cambridge University Press, Cambridge, UK.

Turner, W. 1548. The names of herbes. Day \& Seres, London, UK. ed. 1881. Facsimile. 1966.

Tutin, T.G., V.H. Heywood, N.A. Burgess, D.M. Moore, D.H. Valentine, S.M. Walters, and D.A. Webb. 1980. Flora europea. Cambridge University Press. 499 pp.

Wellman, M. 1906-1914. Pedaniio Dioscuridis Anazarbei De materia medica libri quinque. Three volumes, reprinted 1958. Weidmann, Berlin, Germany.

Woodward, M. 1927. Gerard's herball. The essence thereof distilled by Marcus Woodward from the edition of Thomas Johnson, 1636. Gerald Howe, Pub., London, UK. p. 275-276.

\section{MANUSCRIPTS}

Bodleian Library, Oxford. ms. Bodley 130. ca 1120. Abbey of Bury St. Edmonds. fol. 26r.

Leyden. Herbal of Apuleius Platonicus. ca. $600 \mathrm{CE}$. Napoli National Library, Italy. Codex Neapolitanus: Dioscoride de Materia Medica, ca. 650. [Source: Blunt and Raphael, 1979]. fol 32.

Vienna National Library, Austria, Cod. Med. Gr. 1: Codex Aniciae Julianae (also known as Codex Constantinopolitanus, Codex Byzantinus, Codex vindobonensis, Dioscoride de Vienne): De Materia Medica, ca. 512. [Source: Der Wiener Dioskurides, 1998 (facsimile ed.). fol. 82v-83r]. 